\title{
Cliticization as prosodic integration: The case of Dutch ${ }^{1}$
}

\author{
GEERT BOOIJ
}

\begin{abstract}
In this paper it is argued that the phonological behavior of clitics should not be accounted for by assuming a special prosodic category "Clitic Group". Clitics are integrated into the preceding or the following prosodic word. As far as Dutch is concerned, it appears that proclitics behave like prefixes, and are Chomskyadjoined to the following prosodic word, whereas enclitics behave like suffixes, and form part of the last foot of the preceding prosodic word. In most cases, there is a general preference for leftward cliticization
\end{abstract}

\section{Introduction}

Clitics form a classic case of non-isomorphy between the syntactic structure and the prosodic structure of sentences. For instance, the relevant aspects of the syntactic structure and the prosodic structure of the simple Dutch sentence Jan kocht het boek 'John bought the book' can be represented as follows:

$$
\begin{aligned}
& {[\text { Jan }]_{N}\left[[\text { kocht }]_{\mathrm{V}}[\text { het } \quad \text { boek }]_{\mathrm{NP}}\right]_{\mathrm{VP}}} \\
& \text { (jan } \left.)_{\omega}\left((\mathrm{k} \cdot \mathrm{x})_{\sigma}(\text { tət })_{\sigma}\right)_{\omega} \text { (buk) }\right)_{\omega}
\end{aligned}
$$

The prosodic structure is non-isomorphic to the syntactic structure: The weak form of the determiner het /at/ depends syntactically on the following noun, but

1. This is the revised version of a paper given at the Prosodic Phonology workshop of the 1994 GLOW meeting in Vienna. I would like to thank the organizers of the workshop, Marina Nespor and Sharon Peperkamp, and Mirjam Ernestus for their comments. Thanks are also due to the anonymous referee for the useful suggestions made. 
prosodically on the preceding verb with which it forms one prosodic word. Thus, it is a typical case of the independence of syntax and phonology elaborated upon by Klavans (1985).

Like Anderson (1992) I will reserve the term simple clitic for clitics that have the same syntactic distribution as the other words of the relevant syntactic category, but that are prosodically deficient in that they need a host word to lean on. Special clitics are clitics with a special syntactic distribution. ${ }^{2}$ In addition, they may also be prosodically deficient. Most of the Dutch clitics that I am going to discuss below are prosodically deficient; moreover, some of them have a special syntactic distribution (Berendsen 1986; Zwart 1992). For instance, the following sentences illustrate that pronominal clitics do not have the same distribution as lexical NPs:
a. dat gisteren Jan /*ie het boek las that yesterday Jan he the book read 'that yesterday, Jan/he read the book'
b. dat ik*de afwas/ ' $t$ Marie heb zien doen that I the dishes it Marie have see do 'that I saw Mary doing the dishes/ it'

There are also many idiomatic expressions in which only the clitic form of pronouns can be used (Berendsen 1986:39-40). For instance, in sentences with pseudo-reflexive verbs it is only the weak form of the second person singular pronoun that can be used:

$$
\begin{aligned}
& \text { Je vergist je/*jou. } \\
& \text { 'You make a mistake.' } \\
& \text { Schaam je/*jou! } \\
& \text { 'Shame upon you!' }
\end{aligned}
$$

In this paper I will defend the hypothesis that the phonological side of cliticization is a matter of prosodic integration into an adjacent prosodic word (cf. Gussenhoven 1989; Lahiri et al. 1989; Anderson 1992: 201). This implies that we do not need a prosodic category "Clitic Group", as suggested originally by Hayes in a paper published as Hayes (1989) and also argued for by Nespor and Vogel (1986). The behavior of Dutch clitics also suggests that the form of prosodic integration of proclitics differs from that of enclitics, and that this difference is paralleled exactly by the prosodic differences between prefixes and suffixes.

2. Note that Zwicky (1977) who introduced the distinction between simple and special clitics, used the term "special clitic" also for clitics whose phonological form cannot be derived from the phonological form of their strong counterparts by means of regular phonological rules. The Dutch clitics discussed here are special clitics in this latter sense since they cannot be derived regularly from their strong counterparts (Berendsen 1986: 39; Booij 1995: chapter 8). 
In line with the remarks in Zwicky (1985), the clitic status of words and the prosodic structure of word + clitic combinations is assumed not to be primarily determined on the basis of stress since function words can be stressless, and nevertheless be independent prosodic words. Also, there are languages in which clitics can bear stress (Nespor 1991). The basic phonological criterion used is whether there are phonological rules that apply to word + clitic combinations that do not apply to phonological phrases; in addition, phonotactic properties might be involved.

\section{The Clitic Group}

Nespor and Vogel (1986: chapt. 5) proposed a prosodic category in between the prosodic word and the phonological phrase, the Clitic Group (C). The argument for assuming this intermediate category is that there are rules which apply (i) in word + clitic combinations, but not in words, or (ii) in words and word + clitic combinations but not in phonological phrases (cf. also Vogel 1989; Nespor 1991). For example, according to Nespor and Vogel (1986) the Latin stress rule that assigns penultimate stress to word + clitic combinations such as rosáque 'and the rose' cannot be taken to be the Main Stress Rule of Latin applying to an extended prosodic word of which the clitic forms a part. The reason is that the Main Stress Rule of Latin only assigns main stress to heavy penultimate syllables, whereas in word + clitic combinations the weight of the syllable does not play a role, witness pairs such as limina - limináque '(and) the thresholds'. The observation that weight does not play a role in the location of the main stress in cliticized forms was also made by Steriade (1988:297-298). In her analysis, there is one stress rule for Latin, but with two domains of rule application: W-words and E-words. E-words are combinations of an orthotonic (that is prosodically independent) word (that is a W-word) and an enclitic. ${ }^{3}$

The Clitic Group is constructed as follows (Nespor and Vogel 1986: 154):

Clitic Group Formation:

I. The domain of the Clitic Group consists of a W containing an independent (that is nonclitic) word plus any adjacent Ws containing (a) a Directional Clitic, or (b) a Clitic such that there is no possible host with which it shares more category memberships.

II. Join into an $n$-ary branching the Clitic Group all Ws included in a string delimited by the definition of the domain of the Clitic Group.

This definition implies that words that are not adjacent to a clitic also form a clitic group by themselves. The problem that the quantity-insensitive Latin stress

3. Steriade does not discuss the position of E-words in the hierarchy of prosodic categories. 
rule for word + clitic combinations would then also apply to words, is solved in Nespor and Vogel (1986) by stipulating that this rule only applies to branching Clitic Groups.

There are two objections to assuming a special prosodic category "Clitic Group" (cf. Booij 1988; Lahiri et al. 1990). In terms of theoretical parsimony it is attractive to try to do without this prosodic category. As we will see below, it is possible to give an account of the relevant data without a prosodic category C. Secondly, the implication of algorithm (4) is that clitics always form a prosodic word of their own, which is a very problematic assumption since the characteristic property of many clitics is that they are prosodically deficient, that is, they do not meet the requirements for canonical prosodic words.

Let us first return to the problem of Latin stress. As pointed out by Steriade (1988: 297) and Kenstowicz (1991: 175-175; 1994: 574-575), the derivation of the stress pattern of limináque does not require a separate rule, but follows from the Latin Stress Rule in combination with the Free Element Condition:

Latin Stress Rule:

a. The final syllable is extrametrical.

b. Stress heavy syllables.

c. Construct binary, left-dominant feet right to left.

d. Assign main stress to the last foot.

First, limina will receive the following metrical structure:

$\begin{array}{ccc}\text { li } & \text { mi } & \text { na } \\ (* & *) & \text { á*ñ } \\ * & & \end{array}$

After the addition of -que, the existing metrical structure of limina will be kept intact, in accordance with Prince's Free Element Condition (cf. Halle and Kenstowicz 1991) which requires that existing metrical structure be respected. The unmetrified syllable na now loses its extrametricality and receives stress. Since this is the rightmost stress of the word, this syllable will also receive main stress:

$\begin{array}{cccc}\text { li } & \text { mi } & \text { na \# } & \text { que } \\ (* & *) & (*) & \text { á*ñ } \\ (* & & *) & \\ & & * & \end{array}$

Although Steriade (1988) distinguished between W-words and E-words, such a distinction is not necessary if we assume that rule (5d), the rule that assigns main stress to the rightmost foot, is a postlexical rule whereas foot construction already starts at the lexical level. In other words, the assumption of a special domain $\mathrm{E}$-word is superfluous once we make use of the organization of the grammar. 
The level of application of main stress assigment is to be seen as a dimension along which languages may differ. As pointed out by Steriade (1988:284) for Ancient Greek, and by Nespor and Vogel (1986) for modern Greek and standard Italian, ${ }^{4}$ enclitics never affect the location of the main stress of independent words. Hence, in these languages, the main stress is determined at the lexical level, and it is only secondary stresses that can be assigned postlexically to enclitic syllables and to extrametrical syllabes that remained unmetrified at the lexical level. Similarly, while Indonesian enclitics cause rightward shift of the main stress, Spanish enclitics do not (Hopper and Traugott 1993: 6). Macedonian is another language in which enclitics cause rightward stress shift, which implies that the Main Stress Rule should apply postlexically.

In conclusion, the stress facts of Greek and Latin do not speak in favor of a special prosodic category Clitic Group, a conclusion also drawn with respect to modern Greek by Malikouti-Drachman and Drachman (1992).

The second objection to the prosodic category Clitic Group is that it presupposes that clitics are canonical prosodic words. Dutch is a clear example of a language for which this does not hold: Most clitics are prosodically deficient. The basic constraints on well-formed prosodic words of Dutch are the following:

a. A prosodic word must contain at least one full vowel.

b. A prosodic word cannot begin with a schwa.

Whereas there is no single noun, verb, adjective or adverb that begins with a schwa, or has schwa as its only vowel, almost all weak forms of Dutch function words violate this constraint:

$$
\begin{array}{ll}
\text { Determiners: } & \text { een } / \text { on/ 'a' } \\
\text { de /də/ 'the' } & \text { het /at/ 'the (strong form /het/), NEUT' }
\end{array}
$$

\begin{tabular}{|c|c|c|c|}
\hline \multicolumn{2}{|c|}{ Personal pronoun } & Weak form & Strong form \\
\hline 1SG SUBJ & $i k$ & $/ \mathrm{lk} / / \partial \mathrm{k} /, / \mathrm{k} /$ & $/ 1 \mathrm{k} /$ \\
\hline 1SG OBJ & $m e / m i j$ & $/ \mathrm{mal}$ & /mعi/ \\
\hline 2SG SUBJ & je/jij & /jə/ & /jei/ \\
\hline 2SG OBJ & je/jou & /ja/ & /jou/ \\
\hline 3SG SUBJ MASC & $h i j$ & /i/ & /hei/ \\
\hline 3SG OBJ MASC & hem & $/ 2 \mathrm{~m} /, / \mathrm{m} /$ & /hem/ \\
\hline 3G SUBJ FEM & $z e / z i j$ & |zal & /zzi/ \\
\hline 3SG OBJ FEM & haar & /dər/, /ər/ & /har/ \\
\hline
\end{tabular}

4. Nespor (personal communication) pointed out to me that in modern Greek there is variation here, correlating with age: Younger people may apply the Main Stress Rule of modern Greek at the level of the word + clitic combination, whereas for older people enclitics do not affect the location of the main stress. 


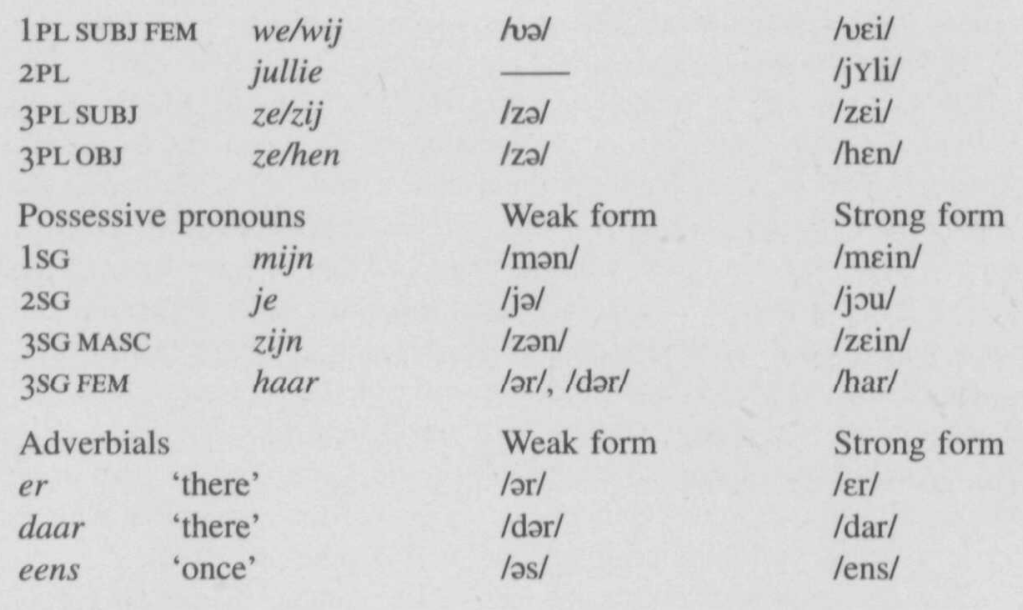

Preposition

te /ta/ 'at'

Thus, phonotactic properties of such weak forms of function words clearly show that they cannot get the status of prosodic word. Moreover, this observation implies that we can already tell from their prosodic structure that they need a host word to attach to, with the exception of ie and its allomorph die (Dutch does have words of lexical categories consisting of a long vowel or diphthong only, such as aa /a/ 'water', ee /e/ 'water', u/y/ 'you', ui /œy/ 'onion', and $e i$ /عi/ 'egg'. 5

This implies that these clitics cannot be dominated by a prosodic category $\mathrm{C}$ because the Clitic Group must directly dominate a prosodic word, and thus the Nespor and Vogel proposal is inadequate for Dutch clitics. ${ }^{6}$

Nespor (1991) argued in favor of the Clitic Group on the basis of the phonological behavior of Italian clitics. As to the necessity of a Clitic Group for Italian, Nespor points out that word + clitic combinations are special in that the rule of Vowel Deletion ("Troncamento") applies obligatorily to them (14a), whereas it is an optional rule for a sequence of non-clitic words that belong to the same Phonological Phrase (14b) or in the same Intonational Phrase (14c):

5. Note that Klavans (1985: 104-105) also uses phonotactic information in determining the direction of cliticization: In the Australian language Nganhcara certain clitics violate the wordinitial phonotactic constraints because they begin with the word-initially impossible consonant clusters /ngk/ and /nhel. Hence, they must cliticize to a preceding host that ends in a vowel, with concomitant resyllabification which breaks up the ill-formed consonant clusters.

6. Zec and Inkelas (1991) also argued that a special prosodic category is superfluous, and that clitics are adjoined to prosodic categories such as the prosodic word and the phonological phrase. 

a. dare + gli $\rightarrow$ dargli (*daregli) 'give them'
b. fare lezione $\rightarrow$ far(e) lezione 'to teach'
c. vuole scrivere gli indirizzi $\rightarrow \operatorname{scriver(e)}$ gli 'please write the instructions'

As far as I can see, an alternative analysis is possible. Note that Italian enclitics are prosodically deficient in that they are monosyllables, whereas words of lexical categories are normally bisyllabic. Therefore, the minimal prosodic word of Italian is bisyllabic (Thornton 1994). This implies that clitics do not form prosodic words of their own, and have to be adjoined to an adjacent prosodic word in order to be prosodically licensed. For instance, the prosodic structure of daregli will be as follows: ${ }^{7}$

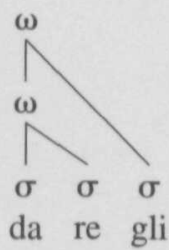

The rule of Troncamento can now be formulated as follows: Delete a $\omega$-final vowel before a consonant. The rule applies obligatorily within $\omega$ (14a), and optionally in larger prosodic domains $(14 b, c)$.

In sum, there are good reasons for developing an account of cliticization phenomena without making use of the prosodic category "Clitic Group".

\section{Prosodic integration}

What is the evidence for the claim that clitics become part of an adjacent prosodic word? Restricting ourselves for a moment to Dutch enclitics, the most straightforward evidence is that cliticization induces obligatory resyllabification in the case of vowel-initial clitics. This follows in my interpretation of prosodic integration since the prosodic word is the domain of syllabification. Hence, the following types of syllabification occur:

$$
\begin{array}{lll}
\begin{array}{l}
\text { kocht het } \\
\text { komt-ie }
\end{array} & \text { 'bought it' } & \left.(\mathrm{kJx})_{\sigma}(\mathrm{t})\right)_{\sigma} \\
\text { pakt het hem } & \text { 'comes he' } & (\mathrm{kom})_{\sigma}(\mathrm{ti})_{\sigma} \\
& \text { 'takes it him' } & (\mathrm{pak})_{\sigma}(\mathrm{t})_{\sigma}(\mathrm{t} ə \mathrm{~m})_{\sigma}
\end{array}
$$

7. Below, I will present more arguments for this kind of prosodic structure. Similar conclusions are reached by Peperkamp (1995). 
The obligatory resyllabification of word + enclitic(s) poses another problem for assigning a clitic the status of prosodic word, since then we would expect the enclitic to form an independent domain of syllabification, contrary to the facts.

Secondly, by integrating enclitics into the preceding prosodic word we predict that rules with the prosodic word as their domain also apply to word + clitic combinations (unless the rule is turned off at the postlexical level). This prediction is correct for Dutch. A typical word domain rule is the rule of Dutch that deletes schwas before an adjacent vowel. The rule applies both lexically, within words, and postlexically, in word + clitic combinations. Note that it does not apply across the word-internal morphological boundary in compounds, since the constituents of a compound form prosodic words of their own:

(17) Prevocalic Schwa deletion:

Words:

kaden

Romein

'quays'

'roman'

$\begin{array}{ll}/ \text { kadə }+ \text { ən } / & {[\text { kadən }]} \\ / \text { romə }+ \text { ein } / & {[\text { romein }]}\end{array}$

Compounds:

medeauteur

'co-author'

modeavond

'fashion night'

/medə + otør/ * * [medotør]

Word + clitic

zette het

haalde hem

'put it'

'fetched him'

pakte ik

'took I'

/modə+ avont/ *[modavont]

The obligatory resyllabification induced by the clitic also explains why an optional rule of Dutch, the deletion of a syllable-final $/ \mathrm{n} /$ after a schwa never takes place before a schwa-initial clitic, although this is possible before a vowelinitial word because such words do not induce obligatory resyllabification. Compare:
a. Zij kochten /koxton/ [koxtə(n)] appels.
'They bought apples.'
b. Zij kochten het /kəxtən-ət/ [koxtənət], *[koxtət] boek. 'They bought the book.'

If $/ n /$-deletion applied in the second example, the preceding schwa would also disappear before the next schwa due to Prevocalic Schwa deletion, and we would end up with [koxtət] which is phonetically wellformed, but the phonetic form of the phrase kocht het 'bought (SG) it'. In other words, the obligatory resyllabification induced by the clitic at the beginning of the postlexical level bleeds the optional, postlexical rule of $/ \mathrm{n}$-deletion, which results in the correct phonetic form [kəxtənət]. ${ }^{8}$

8. A more detailed analysis of this postlexical process is given in Booij (1995: 139-141). 
A third relevant rule of Dutch is the rule of Homorganic Glide Insertion. This rule inserts a glide between two adjacent vowels; the quality of the glide is determined by the first of the two adjacent vowels: Roughly, [j] is inserted after front vowels, and [w] after back vowels. The rule applies obligatorily within prosodic words, and optionally in larger domains such as compounds and phrases (Booij 1995). The crucial observation is that it also applies obligatorily within word + clitic combinations:
a. Ik zie het [sijat] boek.
'I see the book.'
b. Ik doe het [duwat] werk.
'I do the work.'

The rules of Prevocalic Schwa deletion and Homorganic Glide Insertion are to be considered as rules that apply in accordance with the principle "Apply a rule as soon as possible." This means that they can already apply lexically because prosodic words are already created at that level. When new domains of application are created at the postlexical level through the mechanism of prosodic integration, they reapply postlexically. This supports Kiparsky's (1985) proposal that phonological rules are not necessarily assigned to a particular component or level but may apply at more than one level. ${ }^{9}$

Some speakers of Dutch have other means of resolving hiatus in word + enclitic combinations, the insertion of $/ \mathrm{n} /$ between the word-final vowel and the clitic-initial vowel:
a. ik zette-n-et
'I put it'
[1ksetənət]
b. (hij) wilde-n-et 'he wanted it'
[vildənət]
c. wilde-n-ie
'wanted he'
[vildəni]
d. (het) gekke-n-is
'the strange thing is'

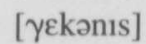
e. (dat) je-n-et
'that you it ...'
[jənət]

The domain of application of this rule can again be considered to be the prosodic word. We do not have to assume a special prosodic domain $\mathrm{C}$ although the rule only applies to word + enclitic combinations. The rule should not apply at the lexical level, unlike Prevocalic Schwa deletion. This follows from the principle that optional rules are always postlexical (Booij 1995: chapter 6). Therefore, /n/-insertion only gets a chance when its domain of application is created through cliticization. For speakers who always insert an $/ \mathrm{n} /$ in such configurations instead of deleting the prevocalic schwa, the rule of Prevocalic Schwa deletion is turned off at the end of the lexical level.

9. However, a rule may be turned off at a later level. For instance, as Kiparsky $(1993: 284)$ observed, the Finnish rule of Consonant Gradation must be blocked from applying to word+ clitic combinations, and hence it is a word level rule. 
The interpretation of encliticization as integration into an adjacent prosodic word also solves the problems encountered by Hualde (1991) in his analysis of the lexical phonology of Basque. In the Baztan dialect there is a rule of Low Vowel Assimilation:

$$
\mathrm{V} \rightarrow[\text {-low }] /[\text { +high }] \mathrm{C}_{0}-
$$

that applies morpheme-internally, in some derived words (Derivation I), in inflected words, and in host + clitic combinations, but not in compounds and certain types of derived words (Derivation II). The following examples from Hualde (1991:31) illustrate this pattern:

\begin{tabular}{llll} 
& \multicolumn{2}{c}{ LVA } & \\
underived forms & yes /ikeś/ & [ikes] & 'to learn' \\
derivation I & yes /mendis-ka/ & [mendiske] & 'hill' \\
derivation II & no /bi-garen/ & [bigaren] & 'second' \\
compounding & no /begi-makui/ & [begimakui] 'cross-eyed' \\
inflection & yes /buru-a/ & [burue] & 'the head' \\
cliticization & yes /tori da/ & [toride] & 's/he has come'
\end{tabular}

Therefore, Hualde (1991:38-39) concluded to the following organization of the grammar of Baztan Basque:
Stratum I:
inflection and derivation I
Stratum II:
derivation II and composition
Stratum III:
cliticization (back to Stratum I)

The rule of Low Vowel Assimilation is assigned to Stratum I, but there is a loop from Stratum III back to Stratum I so that the rule can also apply to word + clitic combinations. Moreover, this ordering implies that inflection is ordered before compounding and derivation II, whereas inflection is normally peripheral to derivation and compounding. Hualde suggests an ad hoc solution for this problem: First the inflectional suffix is attached to a derivational suffix, and then the inflected derivational suffix is attached to a stem.

The correct application of Low Vowel Assimilation can be achieved without level ordering, by assigning this rule the prosodic word as its domain of application. Inflectional suffixes, and derivational suffixes of class I can be interpreted as cohering suffixes, that is they form a prosodic word with the preceding phonological string. Compounds, on the other hand consist of more than one prosodic word. The suffixes of class II will be qualified as noncohering suffixes which form a prosodic word of their own. The attachment of clitics then induces application of Low Vowel Assimilation because they are prosodically incorporated into the preceding prosodic word, its host. Thus, at the postlexical level cliticization creates new domains of application for rules that apply within the prosodic word. 
This leads to the conclusion that the kind of level ordering proposed by Hualde for Basque, and its awkward consequences can be avoided, given our interpretation of cliticization as prosodic incorporation.

\section{Proclitics versus enclitics}

Dutch clitics that have a schwa as their only vowel can be assigned a syllable node at the lexical level. However, these syllables cannot be dominated by higher prosodical structure such as the prosodic word because they do not contain a full vowel. There are then two logical possibilities for the incorporation of clitics into adjacent prosodic words: Adjunction to an adjacent prosodic word, or incorporation into an adjacent prosodic word. In the latter case there are three options: Incorporation into the adjacent foot, adjunction to the adjacent foot, or direct attachment to the prosodic-word node. Below I will discuss the choice between these three structural possibilities. The basic claim I will defend is that Dutch proclitics are adjoined to the following prosodic word, and that enclitics are incorporated into the preceding prosodic word.

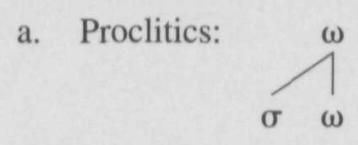
b. Enclitics:
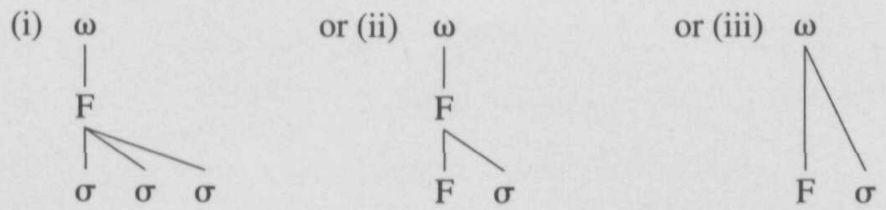

Structure (24a), for which I will present empirical evidence below, violates part of the Strict Layer Hypothesis (cf. Nespor and Vogel 1986) because a syllable node is dominated directly by a $\omega$-node. That is, the intermediate F-level is skipped. It thus appears that we have to relax the prohibition on level skipping in that one level may be skipped. ${ }^{10}$ Recall that a syllable headed by a schwa cannot form a foot of its own. Moreover, the proclitic syllable cannot be made part of the following foot, because Dutch feet are left-headed.

As to the choice between the three structures in (24b) the following should be said. The structure (24b-ii) presupposes that feet may be built recursively. Like structure (24a), this violates another part of the Strict Layer Hypothesis, the

10. Itô and Mester (1992) have also argued for Japanese that certain syllables must remain unfooted. 
claim that prosodic categories cannot be recursive. It appears from the literature, and from structure (24a) that we have to relax this constraint slightly to the extent that recursivity of the category $\omega$ should be allowed for. McCarthy and Prince (1994:85) argue that universally, this constraint should be maintained as far as syllables and feet are concerned, but not for the category $\omega$.

Structure (24b-iii), in which the enclitic syllable is not made part of a foot, but is directly dominated by the $\omega$-node has the disadvantage that it does not relate the empirically established greater degree of prosodic cohesion of enclitics compared to proclitics to the fact that Dutch feet are left-headed, and that therefore a weak enclitic syllable can be added at the right side of a foot without violating left-headedness.

The third option, (24b-i), which I will choose here, is allowing for ternary feet when we have two adjacent syllables headed by schwa. In that case, there is no recursivity of $\mathrm{F}$, but the clitic syllable is incorporated into the last foot of the preceding prosodic word. The only consequence is that we have to allow for ternary feet. Let us assume that feet binarity is universally preferred, but can be violated in order to get an optimal prosodic integration of syllables headed by schwa, which cannot form feet of their own. In sum, it seems that prosodic integration of clitic syllables takes place at the lowest level possible. Of the following constraints, only those in (25b) are violated minimally if necessary:

a. No recursivity of $\sigma$ and $\mathrm{F}$.

Dutch feet are left-headed.

Schwa-syllables cannot head a foot.

b. No recursivity of $\omega$.

Feet are binary.

No skipping of levels.

The consequence of this analysis is that, prosodically, enclitics are identical to suffixes, and proclitics to prefixes:

\section{kochten het /koxtan at/ 'bought(PL) it'}

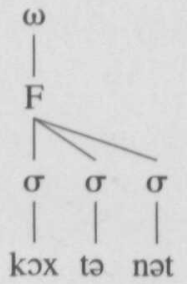

adel-lijk /adal + lək/
'of nobility'

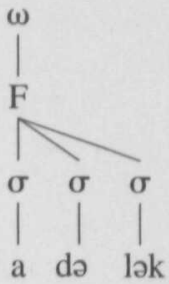

Since the enclitic completely incorporates into the preceding word, obligatory resyllabification is induced, because the prosodic word is the domain of 
syllabification. Resyllabification is restricted to Coda Erasure of the consonants of the final syllable of the already syllabified part of the string (Rubach and Booij 1990a).

Similarly, proclitics and prefixes get the same prosodic structure, for example de keer 'the turn' and bekeer 'to convert':

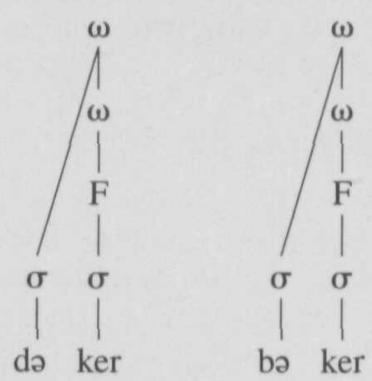

In the case of prefixes there is additional evidence for the claim that the stem forms a prosodic word of its own, without the prefix. As argued in Booij (1985b), Dutch has a rule that optionally deletes one of two identical prosodic words; the prosodic word can be part of a (derived or compound) word. The following examples illustrate this:

$$
\begin{aligned}
& \text { a. rood- of groenachtig } \\
& \text { land- en tuinbouw } \\
& \text { be-en verplanten } \\
& \text { b. herenschoenen en -jassen } \\
& \text { *bevaren en -rijden }
\end{aligned}
$$

'reddish or greenish' 'agriculture and horticulture' 'to plant and transplant' 'men's shoes and men's coats' 'to sail and to ride'

Crucially, we cannot delete a prefix under identity with another prefix. This follows if prefixes do not have the status of prosodic words, as proposed.

The proposed prosodic status of proclitics is confirmed by the fact that the rule of Prevocalic Schwa deletion does not apply to proclitics that are attached to a vowel-initial host, except in very casual speech:
a. we eten 'we eat'
b. de avond 'the evening'
lva etən/ [vəetən]
/də avond/ [dəavont]

Recall that the domain of application of that rule is the prosodic word. That is, the relevant sequence schwa-vowel must be dominated by the same $\omega$-node. This is not the case in the structure proposed for proclitics here given the following definition of dominance (Chomsky 1986: 7):

Dominance:

$\alpha$ is dominated by $\beta$ only if it is dominated by every segment of $\beta$. 
In the example we eten the clitic-schwa $(\alpha)$ is not dominated by the prosodic word node $(\beta)$ because it is not dominated by the lowest $\omega$-node. Thus, the obligatory deletion of the schwa is blocked. (It is only in very casual speech that Prevocalic Schwa deletion may apply across $\omega$-boundaries.)

The rule of $/ \mathrm{n} /$-insertion that inserts $/ \mathrm{n} /$ in a hiatusposition created by cliticization does not apply to proclitic + host combinations. This is predicted by the proposed structure, because $/ \mathrm{n}$-insertion also has $\omega$ as its domain:

$$
\begin{array}{lll}
\text { je eet /jə et/ } & \text { 'you eat' } & *[\text { jənet }] \\
\text { de avond /də avond/ } & \text { 'the evening' } & * \text { [dənavont }]
\end{array}
$$

A by now well-known observation concerning the prosodic nature of prefix boundaries is that in many languages prefix boundaries coincide with syllable boundaries, and are similar to word boundaries in that respect (Booij and Rubach 1984; Rubach and Booij 1990b). This also means that prefixation does not induce obligatory resyllabification, and a complex word like Dutch verassen 'to incinerate' will be syllabified as follows, thus seemingly violating the universal CV-rule:

$$
\left[\operatorname{ver}[\mathrm{as}]_{\mathrm{N}}\right]_{\mathrm{V}} / \mathrm{ver}+\mathrm{as} /(\mathrm{ver})_{\sigma}(\mathrm{as})_{\sigma}
$$

The same applies to proclitics in which the schwa is followed by a consonant. The consonant can remain part of the clitic syllable; that is, there is no obligatory resyllabification such that the clitic-final consonant becomes the onset of the next syllable:

$$
\begin{array}{lll}
\text { zijn aard 'his nature' } & \text { /zən ard/ } & (\text { zən })_{\sigma} \text { (art) } \\
\text { een aap 'a monkey' } & \text { /ən ap/ } & \text { (ən })_{\sigma}(\text { ap })_{\sigma}
\end{array}
$$

The prosodic identity between prefixes and proclitics on the one hand, and suffixes and enclitics on the other hand, as claimed here for Dutch, is in line with the the observation that diachronically proclitics may change to prefixes, and enclitics to suffixes (Hopper and Traugott 1993: 132), so-called morphologization.

Interestingly, Malikouti-Drachman and Drachman (1992) observed for modern Greek that proclitic + host combinations behave exactly like prefixed words with respect to a number of phonological rules, which also suggests their prosodic identity. For instance, a nasal at the end of both prefixes and clitics optionally voices a following stop.

Clitics that consist of a consonant only, must also be incorporated into the adjacent prosodic word node. The Dutch clitics involved are $k$ ' $\mathrm{I}$ ' and $t$ 'it'. If they are procliticized, the only option when they are sentence-initial, they may be assumed to adjoin to the next $\omega$-node. They cannot adjoin to the next $\sigma$-node, because they can create consonant-clusters that do not form wellformed onsets, such as $/ \mathrm{kb}-/$ in $k$-ben ' $\mathrm{I}$ am', and $/ \mathrm{tf}-/$ in $t$-valt 'it falls'. That is, 
they must have the status of a word-initial obstruent appendix. On the other hand, as enclitics they appear to belong to the last syllable of the preceding word: They exhibit coocurrence restrictions with the final consonants of the preceding words. That is, these vowelless clitics can be used only if they form a well-formed coda with the preceding consonant. Hence, we find the following pattern of possibilities:

$$
\begin{array}{ll}
\text { Well-formed: } & \text { Zal } k \text { [zalk] 'shall I', kan } k \text { [kajk] 'can I', mag } t \\
& \text { [maxt] 'may it', heb } t \text { [hept] 'have it' } \\
\text { Ill-formed: } & \text { Moet } k *[\text { mutk] 'must I', mag } k * \text { maxk] 'may I', heb } \\
& k \text { [*hepk] 'have I' }
\end{array}
$$

That is, since the clusters /tk, $\mathrm{xk}, \mathrm{pk} /$ are impossible codas, in these contexts the schwa-initial allomorph of the clitic has to be used. The /t/ differs from the / $\mathrm{k} /$ in that it has more combinatory possibilities: In Germanic languages coronal obstruents form appendices at the end of the prosodic word (Booij 1995). Thus, consonantal clitics exhibit the same kind of asymmetry as clitics with a vowel: Proclitics are directly adjoined to the $\omega$-node, whereas enclitics are adjoined at the lowest level that is possible.

\section{The direction of cliticization}

A related question is whether the direction of prosodic integration is predictable. According to Klavans (1985:98), directionality is a parameter, to be fixed for each individual clitic. Anderson (1992: 203), on the other hand, proposed that the direction of phonological attachment is not an individual property of clitics but determined by the language's rule of Stray Adjunction. The data of Dutch suggest that this is basically the right approach. However, to be more precise, we should not call it a parameter that is fixed in absolute terms for each language (in the case of Dutch as "leftward"). Rather, there is a preferred direction of attachment, in which a minimal number of constraints of the language is violated, but the other direction is also possible. Moreover, individual clitics may be specified as to their direction of attachment, for instance Dutch -ie and the modern Greek possessive clitics (Nespor and Vogel 1986: 153).

To begin with schwa-initial clitics, the rule for Dutch is that, preferably, adjunction takes place to the left. That is, encliticization is preferred to procliticization. This can be related to the fact that Dutch has left-headed feet, and that procliticization therefore creates non-optimal prosodic structures. In addition, encliticization avoids the creation of prosodic words that begin with a schwa. These two factors explain the encliticization preference.

Interestingly, the dominance of enclisis can also be seen in the way that 
word + clitic combinations were spelled in Medieval Dutch, when no standard orthography was available (in modern Dutch clitics are spelled as separate words). For instance, the following spelling forms are the usual ones in the case of sentences with clitic pronouns (Ernestus 1994):

\begin{tabular}{|c|c|c|}
\hline & /dat at/ & 'that(COMP) it \\
\hline offet (of het) & /of at/ & 'if it' \\
\hline $\begin{array}{l}\text { wantet (want het) } \\
\text { alst (als het) }\end{array}$ & $\begin{array}{l}\text { hant at/ } \\
\text { /als t/ }\end{array}$ & $\begin{array}{l}\text { 'because it' } \\
\text { 'if it' }\end{array}$ \\
\hline heefse (heeft ze) & /heft sa/ & 'has them' \\
\hline wijt (wij het) & /wei t/ & 'we it' \\
\hline
\end{tabular}

In the spelling intervocalic consonants are geminated because otherwise the preceding letter would be interpreted as a long vowel. Thus, the spelling dattet is parallel to that of a word like nattar /natar/ 'wetter'. Moreover, whereas the form hebbe [heba] 'have', with a final schwa, occurs as separately written form, this form never appears written as one word with ic ' $\mathrm{I}$ ', that is as hebbeic; thus, the spelling also reflects the effect of obligatory Prevocalic Schwa deletion in cliticized forms.

The preference for enclisis can also be concluded from cases with vowelless clitics. Berendsen (1986: 80) observed that there are minimal pairs that can perceptually be distinguished, and thus show the preference for enclisis:

$$
\begin{array}{lll}
\text { (Dat) zal'k eten } & (\text { zalk })_{\sigma}(\mathrm{e})_{\sigma}(\text { tən })_{\sigma} & \text { 'that I will eat' } \\
(\text { Jan }) \text { zal keten } & (\text { zal })_{\sigma}(\text { ke })_{\sigma}(\text { tən })_{\sigma} & \text { 'John will fool' }
\end{array}
$$

As pointed out in the preceding section, consonantal enclitics exhibit cooccurrence restrictions with the last consonant of preceding words. Thus, we do not find a sequence like moet $k$ 'must I'. In such cases, one might think, the consonantal clitic could still be used as a proclitic before an adjacent vowelinitial word. In such a way the creation of ill-formed consonant clusters can be avoided. However, this appears not to be the case. So, of the following two possible solutions, it is only the second one that is allowed:

$$
\begin{aligned}
& \text { *(Dat) heb kaan (hep) })_{\sigma}(\mathrm{kan})_{\sigma} \quad \text { 'that I wear' } \\
& \text { that have I on } \\
& \text { (Dat) hebikaan } \quad(\mathrm{h} \varepsilon)_{\sigma}(\mathrm{pak})_{\sigma}(\mathrm{an})_{\sigma}
\end{aligned}
$$

In sentence-initial position, however, there is no choice, and the schwa-initial and consonantal clitics can only be incorporated into the following prosodic word. The fact that clitics can occur in that position proves that there is no individual property of directionality for such clitics: 


$\begin{array}{ll}\text { Er staat een paard. } & \text { [orstat] } \\ \text { 'There stands a horse.' } & \\ \text { Het gaat wel goed. } & \text { [otxat] / [txat] } \\ \text { 'It goes well.' } & \\ \text { Ik zal komen. } & \text { [1ksal] [ksal] } \\ \text { 'I will come.' } & \end{array}$

In such cases, a glottal stop will be inserted before the sentence-initial vowel. Inversely, at the end of a sentence clitics can only encliticize.

There are a few exceptions to the principle that the direction of cliticization is not an individual property of the clitic itself: The clitic ie /i/ appears to be inherently directional since it can only be attached to a host on its left. That is, it cannot occur in sentence-initial position:

$$
\begin{aligned}
& \text { Komt-ie? 'Does he come? (kom) })_{\sigma}(\mathrm{ti})_{\sigma} \\
& \text { *Ie komt. 'He comes.' }
\end{aligned}
$$

Therefore, we have to assign a prosodic subcategorization to this pronoun: It must be preceded by a prosodic word (Booij and Lieber 1993). By assigning this pronoun such a prosodic subcategorization of the form $\left.]_{\mathrm{F}^{--}}\right]_{\omega}$, it is also expressed that, although it is prosodically not deficient since it has a full vowel, nevertheless it cliticizes.

The pronoun ie has an allomorph die that also cliticizes obligatorily. When the host that it attaches to (complementizers and third person singular forms of the verb) ends in an obstruent, the /d/ will be devoiced to [t] by a rule of obstruent devoicing to be discussed below; subsequently, degemination may take place:

$$
\begin{array}{lll}
\text { kan-die } & \text { 'can he' } & \text { [kandi] } \\
\text { komt-die } & \text { 'comes he' } & {[\text { komti] }} \\
\text { of-die } & \text { 'whether he' } & \text { [ofti], *[ovdi] }
\end{array}
$$

That is, both allomorphs of the weak pronouns for 'he' must be assigned this prosodic subcategorization.

In the case of weak pronouns such as $j e, w e$ and $z e$, and the definite determiner de resyllabification cannot be used to determine the direction of cliticization because the initial consonants of these pronouns cannot form a wellformed onset with the final consonant of the potential host. In terms of optimal metrical structure enclitization is to be preferred, but since these clitics begin with a consonant, procliticization does not create prosodic words that begin with a schwa. That is, proclitization gives a better result here than in the case of schwa-initial clitics.

Although in this case resyllabification cannot be used as evidence for the direction of cliticization, we know that encliticization is at least an option since the personal pronouns discussed can contract with a preceding complementizer which shows the prosodic cohesion with the preceding word: 
(41)

$\begin{array}{llll}\text { dat je } & \text { /dat jə/ } & \text { [dajə] } & \text { 'that you' } \\ \text { dat we } & \text { /dat və/ } & \text { [dave] } & \text { 'that we' } \\ \text { dat ze } & \text { /dat za/ } & \text { [dasa] } & \text { 'that they' }\end{array}$

Similarly, the weak pronoun $/ \mathrm{k} /$ of $i k$ ' $\mathrm{I}$ ' contracts with a preceding auxiliary:

$\begin{array}{lll}\text { wil ik } & \text { 'want I' } & \text { [vik] } \\ \text { zal ik } & \text { 'will I' } & \text { [zak] } \\ \text { kan ik } & \text { 'can I' } & \text { [kajk] } \\ \text { moet ik } & \text { 'must I' } & \text { [muk] } \\ \text { mag ik } & \text { 'may I' } & \text { [mak] } \\ \text { heb ik } & \text { 'have I' } & \text { [hek] }\end{array}$

This again proves the cohesion between clitic and preceding word.

The phonological structure of the definite determiner de /da/ implies that it allows for both directions of cliticization, and this appears to be the case. If it is encliticized, the /d/ is devoiced through the rule of Word-internal Devoicing (41); if it is procliticized, it does not change, but may trigger regressive voice assimilation of final obstruents of preceding prosodic words (Gussenhoven 1989; Lahiri, Jongman and Sereno 1990):

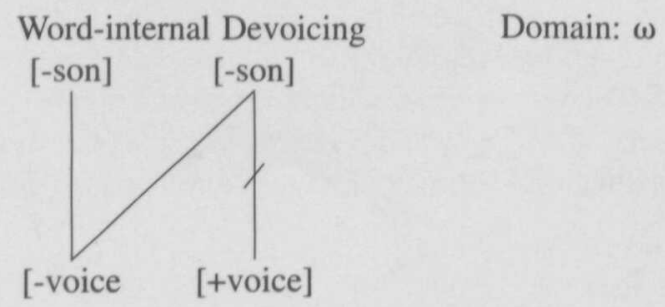

$$
\begin{aligned}
& I k \text { lees de krant. } \\
& \text { 'I read the paper.' } \\
& \text { encliticization: (lees de })_{\omega}(k r a n t)_{\omega} \text { [lesta] } \\
& \text { procliticization: (lees) } \omega_{\omega}(\text { de krant })_{\omega} \text { [lezdə] }
\end{aligned}
$$

The rule of Word-internal Devoicing does not imply that there are no voiced obstruent clusters within Dutch prosodic words, witness past tense singular forms like graafde 'dug' [gravdə] en verbaazde 'surprised' [vərbazdə]. In these cases the two obstruents share their feature [+voice], and hence they are immune to devoicing because of the Geminate Constraint (Hayes 1986; Booij 1995).

There are also function words that contain a full vowel. Since they are not prosodically deficient, there is no need to cliticize them. Yet, it appears that they can be optionally incorporated in the preceding prosodic word. The relevant function words are the following: 


$\begin{array}{lll}\text { dit } & \text { 'this' } & / \mathrm{dit} / \\ \text { deze } & \text { 'this, these' } & / \mathrm{deza} / \\ \text { dat } & \text { 'that' } & / \mathrm{dat} / \\ \text { die } & \text { 'that, those' } & / \mathrm{di} / \\ \text { daar } & \text { 'there' } & / \mathrm{dar} /\end{array}$

These words can receive a $\omega$-node of their own, and hence they need not be cliticized. Indeed, it appears that such function words are only optionally encliticed (Zonneveld 1983), as can be concluded from the two possible phonetic forms of the following phrases:

$$
\begin{array}{lll}
\begin{array}{l}
\text { op die manier } \\
\text { is dat goed }
\end{array} & \text { 'in that manner' } & \text { [obdimanir] or [optimanir] } \\
\text { wie is daar? } & \text { 'who is there?' } & \text { [1zdatxut] or [1statxut] } \\
& \text { [vijizdar] or [vijistar] }
\end{array}
$$

When the function word is not encliticized, the Dutch rule of Regressive Voice Assimilation applies, which voices obstruents before voiced stops in phonological phrases, that is across prosodic word boundaries. When encliticization takes place, however, the initial /d/ of these function words is devoiced due to Wordinternal Devoicing.

A similar situation obtains for the personal pronoun $i k / \mathrm{k} /$. Prosodically, it can stand on its own. Yet, being a vowel-initial function word, it preferably encliticizes, thus avoiding an onsetless syllable.

The rule of word-internal devoicing also affects the /d/-initial clitic $d^{\prime} r$ 'her' /dər/, which appears to cliticize optionally leftward, because we may get devoicing of the $/ \mathrm{d} / \mathrm{after}$ a voiceless obstruent.

$$
\text { Ik mag d'r wel. 'I like her.' [maxtər], [maydər] }
$$

The following question now arises: What happens to $d^{\prime} r$ in sentence-final position, when there is no host word available on the right? Is prosodic incorporation to the left obligatory in such cases? The answer is in the negative. Lahiri, Jongman and Sereno (1990:120) concluded that in such cases we still have both possibilities, progressive or regressive voice assimilation, which suggests that even there prosodic integration is optional. They proposed that a form like [ma $\mathrm{d} d ə \mathrm{r}$ ], with regressive voice assimilation, is derived by leaving the clitic outside the prosodic word, that is it is either Chomsky-adjoined to the preceding $\omega$, or directly dominated by the last phonological phrase node.

In sum, we have come to the following classification of clitics in Dutch:
a. words that require a host on their left: Ie and its allomorph die;
b. words that are prosodically deficient, and must therefore cliticize leftward or rightward; when there is a host available on the left, leftward cliticization is preferred; the preference for encliticization is particularly strong for schwa-initial clitics; 
c. function words that are not prosodically deficient, and which cliticize optionally leftward.

This classification makes it also clear that the notions "function word" and "clitic" cannot be identified.

The adjunction of function words with full vowels to the preceding prosodic word also implies that their dominating $\omega$-nodes will be erased since a syllable cannot belong to two prosodic words simultaneously.

\section{Cliticization and final devoicing}

The interaction between cliticization and final devoicing has been the topic of some debate in the literature on Dutch (Berendsen 1983, 1986; Booij 1985a). As argued in Booij and Rubach (1987), the rule of Final Devoicing of Dutch that devoices obstruents in coda position is a lexical postcyclic (= word level) rule. This correctly predicts that the resyllabification induced by encliticization does not affect the specification for [voice] of word-final obstruents, given that clitics are prosodically integrated at the postlexical level. Thus, in the relevant phonetic forms we find devoiced obstruents in onset position:

$$
\begin{aligned}
& \text { vond-ik /vond ak/ 'found I' (von })_{\sigma} \text { (tak) } \\
& \text { vond-ie /vond-i/ 'found he' (von })_{\sigma}(\mathrm{ti})_{\sigma} \\
& \text { vond et /vond at/ 'found it' (von })_{\sigma}(\mathrm{tat})_{\sigma}
\end{aligned}
$$

However, there appears to be variation here in that for certain frequent verbs the variants with voiced obstruents are also found, but only in cases where there is an underlying stem-final voiced obstruent. This suggests that frequent verb + clitic combinations are lexically stored. Consequently, the resyllabification induced by the attachment of the clitic will bleed the word level rule of Final Devoicing, as is illustrated here for heb ik 'have I':

$$
\begin{array}{lll}
\text { lexical clitic: } & / \mathrm{h} \varepsilon b \mathrm{lk} / & (\mathrm{h} \varepsilon)_{\sigma}(\mathrm{b} ı)_{\sigma} \\
\text { postlexical clitic: } & / \mathrm{h} \varepsilon \mathrm{b} \mathrm{k} / & (\mathrm{h} \varepsilon)_{\sigma}(\mathrm{p} \mathrm{k})_{\sigma}
\end{array}
$$

Both phonetic forms occur. Less frequent verbs with stem-final voiced obstruent such as verbind 'to connect', verwond 'to injure', and vermoord 'to murder' do not surface with a voiceless obstruent before the clitic:

$$
\begin{array}{lll}
\text { verbind-ik } & \text { 'connect I' } & \text { [vərbıntık], *[vərbındık] } \\
\text { verwond-er } & \text { 'injure her' } & \text { [vəruəntər], *[vərvəndər] } \\
\text { vermoord-em } & \text { 'murder him' } & \text { [vərmo:rtəm], *[vərmordəm] }
\end{array}
$$

In other words, in the lexicalized cases the clitic has become a suffix. This is in line with the general pattern of grammaticalization that we find: 

lexical item > clitic > affix (Hopper and Traugott 1993:132)

and we might now refine this pattern as follows:

$$
\text { lexical item }>\text { postlexical clitic }>\text { lexical clitic }>\text { affix }
$$

There is quite some evidence for lexicalized word + clitic combinations. To begin with, already in Medieval Dutch the sequence heb ik 'have I' is very frequently written as one word, the most popular orthographical form being hebbic. This spelling indicates that the $/ \mathrm{b} /$ is realized as a voiced obstruent. The geminate spelling of the /b/ confirms this. If hebic had been written with a single $b$, this form could still have been interpreted as a sequence of heb and $i c$, with a possible interpretation of heb as [hep]. The geminate spelling excludes the possibility of such an interpretation.

The cases of contraction discussed above also have a lexicalized nature since this kind of contraction only occurs in combinations of auxiliaries and enclitics. As pointed out by Gussenhoven (1985), the verbs hebben 'to have' and zijn 'to be' also contract with preceding pronouns and complementizers:

\begin{tabular}{|c|c|c|}
\hline$i k$ heb & 'I have' & 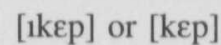 \\
\hline je hebt & 'you have' & [jept] \\
\hline hij heeft & 'he has' & [heift] \\
\hline$z i j$ heeft & 'she has' & [zeft] \\
\hline we hebben & 'we have' & [vebon] \\
\hline ze hebben & 'they have' & [zebən] \\
\hline b. hij is & 'he is' & [heis] \\
\hline$z i j$ is & 'she is' & [zeis] \\
\hline dat is & 'that is' & [das] \\
\hline wat is (dat)? & 'what is' & [vas] \\
\hline dit is & 'this is' & [dis] \\
\hline
\end{tabular}

For most verbs such contractions are impossible. For instance, je houdt 'you hold' cannot be realized as *[jout], parallel to the phonetic realization of je hebt as [jept].

More evidence for the possibility of lexicalization of word + clitic combinations can be found in Pullum and Zwicky (1983) for English $n^{\prime} t$, and for Polish clitics in Booij and Rubach (1987) (aptly summarized in Spencer 1991:370) and Hopper and Traugott (1993: 137). The Polish evidence for the lexical status of certain clitics is that the rules of the lexical phonology of Polish such as the Main Stress Rule and Vowel Raising appear to apply to certain word + clitic combinations, whereas other clitics do not trigger the application of the rules of the lexical phonology. That is, the former clitics have become like suffixes, although they still exhibit a certain degree of positional mobility that real suffixes do not have.

The effect of lexicalization of a word + clitic combination is that the clitic 
becomes an affix. In other words, the change of clitic to affix takes place via a stage of lexicalization.

Lexicalization may also explain the phenomenon of inflection of complementizers. This kind of inflection is remarkable because it is primarily lexical categories that exhibit inflection. Personal subject pronoun clitics may cliticize to the preceding host, the complementizer. When such combinations lexicalize, the complementizer-clitic combination can be interpreted as an inflected complementizer that has to agree with the subject pronoun. This is the case for West-Flemish (Bennis and Haegeman 1984; Spencer 1991:30) where the form of the inflections on the complementizer clearly reflects their historical origin as subject clitics. Yet, they are not subject pronouns anymore, since an additional explicit pronominal or lexical subject is possible.

\section{Conclusions}

In this paper I have tried to argue that the phonological behavior of Dutch clitics does not necessitate the assumption of a special prosodic category, the Clitic Group. It was argued that the phonological behavior of clitics in Dutch can be accounted for by the hypothesis of prosodic integration, which claims that clitics are incorporated into an adjacent prosodic word. I have tried to make the notion of prosodic integration more precise by looking in detail at how the phonological rules of Dutch apply to word + clitic combinations. Thus, it became clear that procliticization differs from encliticization in that proclitics, like prefixes, are adjoined to the following prosodic word node, whereas enclitics, like cohering suffixes, are incorporated into to the preceding prosodic word, and become part of the last foot of that prosodic word.

Another theoretically important conclusion is that the direction of cliticization is not a parameter. Rather, there is a preferred direction that creates the most optimal phonological configuration, but the other direction is also possible. In case there is no violation of phonological constraints, cliticization of function words is optional, because in such cases cliticization does not improve the phonological representation of the sentence.

Received 21 June 1994

Revised 2 August 1995

Department of Linguistics Free University, Amsterdam

\section{References}

Anderson, Stephen (1992). A-morphous Morphology. Cambridge: Cambridge University Press. Bennis, Hans and Liliane Haegeman (1984). On the status of agreement and relative clauses in West-Flemish. In Sentential Complementation, Wim de Geest and Yvan Putseys (eds.), 33-53. Dordrecht: Foris. 
Berendsen, Egon (1983). Final devoicing, assimilation, and subject clitics in Dutch. In Linguistics in the Netherlands, Hans Bennis and W.U.S. van Lessen Kloeke (eds.), 21-30. Dordrecht: Foris.

- (1986). The Phonology of Cliticization. Dordrecht: Foris.

Booij, Geert (1985a). Lexical phonology, final devoicing, and subject pronouns in Dutch. In Linguistics in the Netherlands, Hans Bennis and Frits Beukema (eds.), 21-30. Dordrecht: Foris.

(1985b). Coordination reduction in complex words: A case for prosodic phonology. In Advances in Non-linear Phonology, Harry van der Hulst and Norval Smith (eds.), 143-160. Dordrecht: Foris.

(1988). Review of Nespor and Vogel (1986). Journal of Linguistics 24: 515-525.

- (1995). The Phonology of Dutch. Oxford: Clarendon Press.

Booij, Geert and Jerzy Rubach (1984). Morphological and prosodic domains in Lexical Phonology. Phonology Yearbook 1: 1-28.

- (1987). Postcyclic versus postlexical rules in Lexical Phonology. Linguistic Inquiry 18: 1-44.

Booij, Geert and Rochelle Lieber (1993). On the simultaneity of morphological and prosodic structure. In Studies in Lexical Phonology, Sharon Hargus and Ellen Kaisse (eds.), 23-44. San Diego: Academic Press.

Chomsky, Noam (1986). Barriers. Cambridge, MA: MIT Press.

Ernestus, Mirjam (1994). Onderzoek naar Middelnederlandse clitica op basis van geschreven tekstcorpora. Unpublished M.A. Thesis,Department of Linguistics, Vrije Universiteit Amsterdam.

Gussenhoven, Carlos (1985). Over de fonologie van Nederlandse clitica. Spektator 15: 180-200.

- (1989). Cliticization in Dutch as phonological word formation. Unpublished manuscript, Catholic University of Nijmegen.

Halle, Morris and Michael Kenstowicz (1991). The free element condition and cyclic versus noncyclic stress. Linguistic Inquiry 22: 457-501.

Hayes, Bruce (1986). Inalterability in CV phonology. Language 62:321-353.

Hayes, Bruce (1989). The prosodic hierarchy in meter. In Phonetics and Phonology: Rhythm and Meter, Paul Kiparsky and Gilbert Youmans (eds.), 1:201-260. New York: Academic Press.

Hopper, Paul J. and Elizabeth Closs Traugott (1993). Grammaticalization. Cambridge: Cambridge University Press.

Hualde, José Ignacio (1991). Basque Phonology. London: Routledge.

Itô, Junko and Armin Mester (1992). Weak layering and word binarity. Unpublished manuscript, University of California at Santa Cruz.

Kenstowicz, Michael (1991). Enclitic accent: Latin, Macedonian, Italian, Polish. In Certamen Phonologicum II, Pier Marco Bertinetto, Michael Kenstowicz and Michele Loporcaro (eds.), 173-186. Torino: Rosenberg and Sellier.

- (1994). Phonology in Generative Grammar. Oxford, United Kingdom: Basil Blackwell.

Kiparsky, Paul (1985). Some consequences of Lexical Phonology. Phonology Yearbook 2: 85-138.

- (1993). Blocking in non-derived environments. In Studies in Lexical Phonology, Sharon Hargus and Ellen Kaisse (eds.), 277-319. San Diego, Calif.: Academic Press.

Klavans, Judith (1985). The independence of syntax and phonology in cliticization. Language 61: 95-120.

Lahiri, Aditi, Allard Jongman and Joan Sereno (1990). The pronominal clitic [dar] in Dutch: A theoretical and experimental approach. Yearbook of Morphology 1990, Geert Booij and Jaap van Marle (eds.), 115-128. Dordrecht: Foris.

Malikouti-Drachman, Angeliki and Gabriel Drachman (1992). Greek clitics and Lexical Phonology. In Phonologica 1988, Wolfgang U. Dressler, Hans C. Luschützky, Oskar E. Pfeiffer and John R. Rennison (eds.), 197-206. Cambridge: Cambridge University Press.

McCarthy, John and Alan Prince (1994). Generalized alignment. Yearbook of Morphology 1993, Geert Booij and Jaap van Marle (eds.), 79-153. Dordrecht: Kluwer. 


\section{G. Booij}

Nespor, Marina (1991). The phonology of clitic groups. In Clitic Doubling and Clitic Groups, Lars

Hellan and Henk van Riemsdijk (eds.), 5:67-90. ESF-Eurotyp Working Papers.

Nespor, Marina and Irene Vogel (1986). Prosodic Phonology. Dordrecht: Foris.

Peperkamp, Sharon (1995). Romance clitics and constraints on phonological constituency. Unpublished manuscript, Department of Italian, University of Amsterdam.

Pullum, Geoffrey K. and Arnold Zwicky (1983). Cliticization versus inflection: The case of English n’t. Language 59: 502-513.

Rubach, Jerzy and Geert Booij (1990a). Syllable structure assignment in Polish. Phonology. 7: $121-158$.

(1990b). Edge of constituent effects in Polish. Natural Language and Linguistic Theory $8: 427-463$.

Spencer, Andrew (1991). Morphological Theory. Oxford: Basil Blackwell.

Steriade, Donca (1988). Greek accent: A case for preserving structure. Linguistic Inquiry 19: 271-314.

Thornton, Anna M. (1994). Italian Prosodic Morphology. Unpublished manuscript, Università dell'Aquila.

Vogel, Irene (1989). The clitic group in prosodic phonology. In Grammar in Progress; GLOW Essays for Henk van Riemsdijk, Joan Mascaró and Marina Nespor (eds.), 447-454. Dordrecht: Foris.

Zec, Draga and Sharon Inkelas (1991). The place of clitics in the prosodic hierarchy. In Proceedings of the West Coast Conference on Formal Linguistics, David Bates (ed.), 10: 505-519. Stanford: Stanford Linguistics Association.

Zonneveld, Wim (1983). Lexical and phonological properties of Dutch voicing assimilation. In Sound Structures: Studies for Anthonie Cohen, Marcel van den Broecke et al. (eds. ). 297-312. Dordrecht: Foris.

Zwart, Jan-Wouter (1992). Notes on clitics in Dutch. Paper presented at the ESF workshop on clitics, Lund, 22 May.

Zwicky, Arnold (1977). On Clitics. Bloomington: Indiana University Linguistics Club.

- (1985). Clitics and particles. Language 61:283-305. 